\title{
The Use of Innovative Nano emulsions and Nano-Silver Composites Packaging for anti-bacterial properties: An article review
}

\author{
H Ahari ${ }^{1^{*}}$ \\ ${ }^{1}$ Department of Food Science and Technology, Science and Research Branch, Islamic Azad \\ University, Tehran, Iran
}

\begin{abstract}
Nowadays, the use of innovative Nanotechnology in the food industry quality control has significantly increased and it is widely employed in numerous fields such as diagnosis of microbial toxin of foods using Nanobiosensors, increasing food shelf-life with the help of Nano-clay and Nano-silver packaging, as well as changing some of the unpleasant organoleptic properties such as taste, color, and smell which are specifically important in marine products, so that the usage of this technology is growing with an increasing pace . Numerous branches of this technology such as Nanoinjection is used in medical fields in order to inject chemical mixtures for chemotherapy to the patients and avoiding the spread of these mixtures in the body organs and blood circulation system, in a way that the target tissue is only affected and goes under chemotherapy.

Correspondence H Ahari, Department of Food Science and Technology, Science and Research branch, Islamic Azad University, Science and Research Branch, Tehran, Iran (email: Dr.h.ahari@gmail.com )
\end{abstract} They are utilized in diverse fields such as laboratory facilities, production of laboratory covers for impeding the penetration of acidic and even microbial materials into the cloths, as well as production of anti-acid tiles and ceramics which resist inflammation, absorption of acidic materials and solvents. Using zinc Nanocomposites like Nano-titanium dioxide in food packaging has also had a paramount effect in controlling the contamination of products and increasing their shelf-life without apparent and physical changes of the product. Besides increasing the shelf-life and lag phase, one of the basic implications of Nano-packaging covers is increasing the durability phase (stability phase) which in line with the discretion of the producer can improve the sensual quality of the packaged samples. These samples can change in terms of texture, smell and color depending on the additives added to the Nano-packaging covers and resolve the unpleasant smells disseminated from chicken, fish and shrimp in most of the cases.

Keywords: Nano Technology, Nano-Silver, Nano-Silver Packaging 


\section{Introduction}

One of the functions of innovative nanotechnology in the field of food industry and nutrition is the production of food capsules. Nano-capsules are a collection of multivitamins and minerals which enable the consumer to survive in the absence of food products for a long time in cases of floods, earthquake, famine, war and the like (Ahari, Dastmalchi, Ghezelloo, Paykan, Fotovat \& Rahmannya 2008).

Since the time of primitive humans, silver has been vastly and commonly employed as an antibacterial metal. For instance, before the second World Ward, in order to prevent the spread of sepsis among soldiers, they placed silver coins on wounds and injuries; or in the time of pharos, so as to mummify the corps, silver metals were used. Moreover, to increase the shelf-life of milk, dairy and vegetables, they used silver containers unknowingly for keeping food products (Moaddab, Ahari, Shahbazzadeh, Motallebi, Anvar, Rahman-Nya \& Shokrgozar 2011).

Nowadays, research on the stability (bioavailability) rate, digestion, and absorption of these capsules are of a paramount importance.

\section{1-Nano-package Covers and Their Mechanism of Function}

One of the main products of nano-technology in the field of food industry is the use of nanopackaging covers including nano-silver, nanoclay, nano-gold, and nano-cupper. Each one of these covers are classified based on the main metal used in them and its property (antibacterial, increasing the surface tension, resisting the penetration of oxygen and moisture into the food product). One of the chief types of these covers, is the nano-silver packaging cover (Moaddab et al. 2011).

It is worth mentioning that, in Islam, silver has a sacred position. Considering the antibacterial property of this metal in the development of modern nano-technology, its implications in the medical sciences, food science and industry, is drastically increasing. Today, by employing the nano-technology and using multiple methods for producing particles in nano-scale and transforming the silver metal to nano-metric scale ( 0 to $50 \mathrm{~nm}$ ), all its antibacterial properties are largely increased and it has gained multiple usages, including its function in packaging covers in order to enhance the shelf-life of food products. The smaller the nano-scale materials, it would be the higher antibacterial effectiveness (Ahari et al. 2008).

In a scale of zero to one hundred, the production of smaller particles nearer to the range of 10 nanometers are preferred due to the increase of antibacterial properties. However, the more the size of particles get closer to this rage, the chance of amassing the particles is sharply increased, to the extent that this phenomenon is one of the most important chemical risks to the safety of food products, since after the transformation of the particles to 
Nano-scale, all physical, chemical, microbial, and even electric ductility of the particles are changed or in some materials, they are extraordinarily increased (Duncan 2011, Carbone, Donia, Sabbatella \& Antiochia 2016). After the entrance of these particles to the biological system of the body, they become amassed in many of the organs like kidney, liver and spleen and lead into carcinogenic, teratogenic and mutagenic symptoms (Shahbazzadeh, Ahari, Rahimi, Dastmalchi, Soltani, Fotovat, Rahmannya \& Khorasani 2009).

\section{2-The Study of Toxicity and Release of the Nanoparticles in the Packaging Covers}

One of the main obsessions of the humans in using the nano-packaging covers, is the lack of nano-particles release from the cover to the packaged product. In case of release, the particles use the food as the conveyor, enter the biological system of body and be accumulated in many of the organs (Moaddab et al. 2011).

After expiration of the product, in order to check the rate of the nano-particles remaining in the packaged products several testing methods such as titration and immigration, as well as adjacency of food with cover are utilized (it is worthy of note that the sensitivity level of titration is many times more than the immigration method). According to the international standard of BPA, is less than 10 ppm rate of remaining nano-particles and the standard of release rate of the nano-particles into the food product is $0 \mathrm{ppm}$. This indicates lack of nano-particles release into the food products (Shahbazzadeh, Ahari, Motalebi, Anvar, Moaddab, Asadi, Shokrgozar \& Rahman-Nya 2011).

In nano-packaging covers, an element was used as conveyor which was mostly the combination of $\mathrm{Tio}_{2} \cdot \mathrm{Tio}_{2}$ has photocalystic properties and induces silver antibacterial properties or any other metal that has been coded on it, and after provoking status, electron returns to the layer before the last in the metal (Hannon, Kerry, Cruz-Romero, Azlin-Hasim, Morris \& Cummins 2016).

Today, in most of the nano-silver packaging covers, the silver particles cover the titanium metal, as $\mathrm{Tio}_{2}$ has sponge features and the silver particles which have been transformed to nanoscale become coded in its pores, and due to the neocatalytic features of titanium, they induce their antibacterial property (Ahari et al. 2008).

\section{3-The Function of Nano-packaging Covers}

Nano-packaging covers are used for 2 and in some cases for 3 purposes. In the first case, these covers are used for increasing the shelf-life of the food products by increasing the duration of the log phase. The more this phase is increased and the more entering the log phase is postponed, the more effective the function and role of packaging cover, since this is important from the microbiological aspect of the food products. It should be pinpointed that the difference in the nano-packaging covers lies in 
increasing the lag phase or the shelf-life (Huang, Li \& Zhou 2015, Srividya, Ghoora \& Padmanabh 2017).

In the second case, so as to change some of the organoleptic properties like smell, taste, and even in some cases, in order to change the flavor nano-packaging covers were used (Farrokhi, Ahari \& Abedini 2016, Ahari, Kakoolaki \& Anvar 2017).

In many materials like airlines, the distribution of food products causes emission of a particular stink that remains in the cabin for a long time and is unpleasant for many of the passengers. Hence, through adding flavor with a packaging covers during the food products preservation, the product will become desirable for the customers ( $\mathrm{Su}, \mathrm{Lin}, \mathrm{Chen}, \mathrm{Wu} \&$ Wang 2017).

In the third case, this is of high importance for marketing and even attracting the customers in the shops pallets which is a topic in the field of food products marketing and not the concern of this article (Tierney 2017).

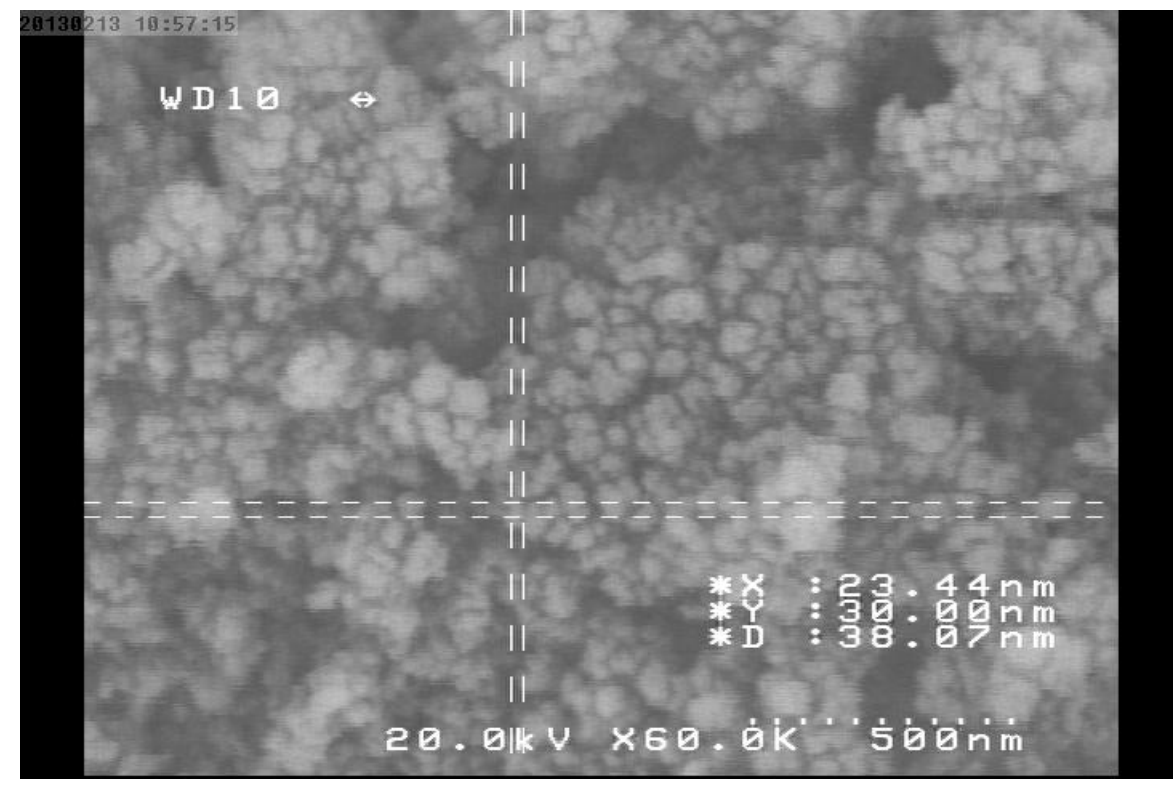

Fig 1: Regulation of Nano particles (Ag) by SEM .

\section{4-Different methods of producing Nano-silver packaging:}

Among the common methods for packaging nano-silver covers, it can be referred to SoL to gel and gel to SoL. One of the simple and relatively cheap methods for producing nanosilver packaging covers is the casting method. Another method which is appropriate from the microbial aspect of food products is the melting solvent (melt mixing) method (Carbone et al. 2016, Su et al. 2017).

The very important point in using each of these methods, is the lack of need to using halogen elements like chlorine, bromine, and 
iodine; because the mixing tendency of silver with the halogen group elements is very high and causes precipitation of silver-chloride, silver-bromide and ...and prevents the realization of antibacterial property of silver nano-particles so that the cover of produced package has no impact on the shelf-life of the food products (Alinejad Dizaj, Mahdaviani, Tabarsi, Ahari, Ebrahimi, Nadji, Emami \& Mortaz 2016).

In some of the microbial tests like total count, serial dilution, and inhibition zone, in case of the existence of the halogen elements and their reaction with silver nano-particles, their negative and incorrect responses in the evaluation of the antibacterial test of the nanosilver covers. Consequently, the covers that have such feature are reported in the reverse form. One of the most important notes in the evaluation of the properties of nano-silver covers, is removing the halogen elements and not using these mixtures in the test (Vera, Echegoyen, Canellas, Nerin, Palomo, Madrid \& Camara 2016, De Silva, Mantilaka, Ratnayake, Amaratunga \& de Silva 2017, D. Li, Ye, Jiang \& Luo 2017).

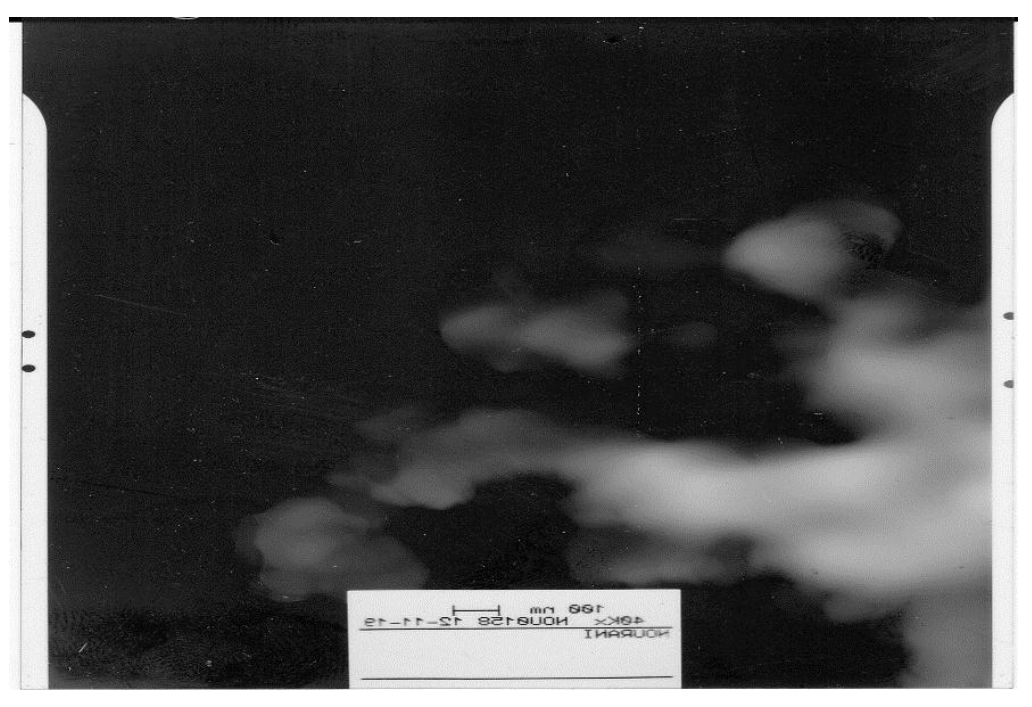

Fig 2 Nano silver particle with TEM

With regard to the conducted researches on the microbial aspects of the packaging covers, the use of Nano-silver lacking the property release to the packaged products and silver Nanoparticles which lack titanium combinations as conveyors of silver Nano-particles have been much more common (Kogure, Akita \& Harashima 2007, Bumbudsanpharoke \& Ko 2015, Gallocchio, Cibin, Biancotto, Roccato, Muzzolon, Carmen, Simone, Manodori, Fabrizi, Patuzzi \& Ricci 2016) . 


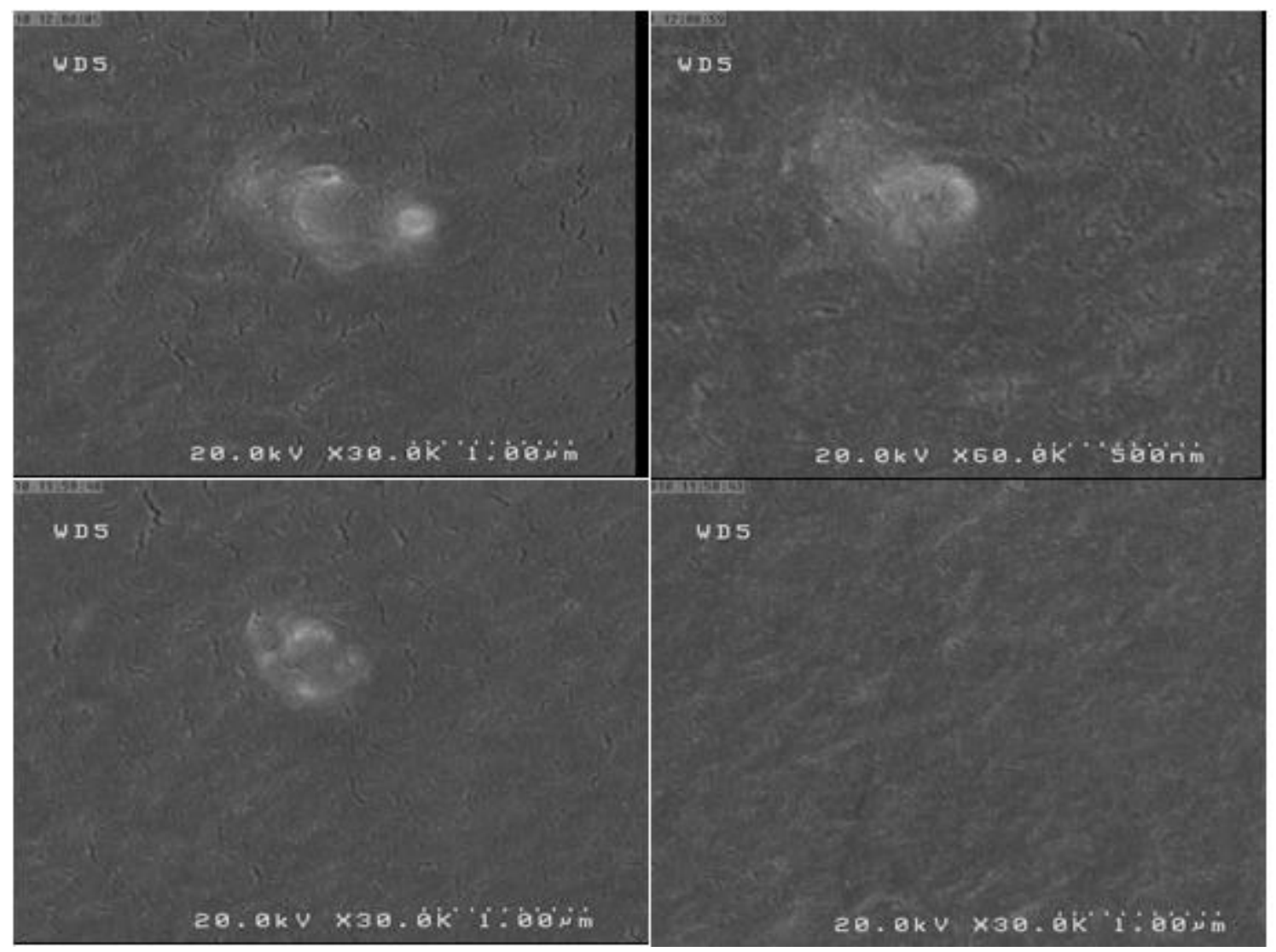

Fig 3 No Homogeneous silver particle on acetonitrile solution

There exists a gap for the evaluation and research of the herbal essence as another effective antibacterial material in the covers. This is while considering the temperature range of the essences, they are very important as due to the use of higher temperature in the electrode, denotation and destruction of sulfuric bounds in the texture and effective herbal mixture would be deactivate in effect.

The use of nano-particles synthetic covers like Nano-clay and Nano-silver can bring about antibacterial property and cause higher consistency of the covers through increasing the adhesion.
Nowadays, considering the large volume of the covers, Nano-covers have a more costeffective final cost in comparison with the covers devoid of Nano-particles, as the smaller the produced particles are in the nonmetric scale, the ration of surface to volume would be drastically increased. For instance, with 10 grams of silver, about billions of Nano-silver particles can be produced. This is to mean that economically, it is more cost-effective for the producers and it would reduce the final cost of the packaged product (Lin, Li, Zhong, Zhao, Xiao \& Wang 2014, D. Li et al. 2017, L. Li, Zhao, Zhang, Yao, Yang, Hu, Wang \& Cao 2017). 
One of the very important points in employing the Nano-packaging covers is the health of food, namely the protection against oxygen, controlled release of the food product, improvement of taste and flavor, transfer of the nutrition via Nano-capsules, and evaluating the quality and safety of food (Luo, Wang, Wang \& Feng 2014, Ramos, Jimenez, Peltzer \& Garrigos 2014, Vera et al. 2016).

The use of Nano-silver particles inside packaging covers increases the volume to surface ratio and the number of metal atoms in each unit of the surface, consequently, it provides a better and more contact with the pathogen M.O.s and is utilized as an antimicrobial material against bacteria, viruses and other M.O.s. Hence, we can produce covers that increase the shelf-life of the food products and decrease the microbial load which are directly related to the size of Nano-particles (Yamada, Kogure, Nakamura, Inoue, Akita, Nagatsugi, Sasaki, Suhara \& Harashima 2005).

Considering the reduction of the food resources and finish of many sources, one of the main obsessions of the todays' world is how to prevent the waste of food products like expensive supplies such as saffron and caviar. This per se is one of the chief reasons for the development of innovative Nano-technology and food industry, quality control, safety and hygiene of the food products.

By far, numerous research projects aimed to increase the shelf-life of food products such as meatloaves, cocktail sausages, beluga caviar, beluga, Iranian saffron, shrimp, rainbow trout, disposable bread and grinded meat, have been conducted through casting and Nano-silver covers based on $\mathrm{Tio}_{2}$. However, there exists a need to utilize other Nano-particles such as copper and clay in combination or herbal additives seed essence, rosemary, Shirazi thyme (Zataria multiflora boiss), and other plants in order to enhance the quality and flavor of the packaged supplies like chicken, fish and shrimp (Moaddab et al. 2011).

One of the pre-occupations of the mankind is the release of Nano-particles; hence, more precise investigations have been carried out on the bio-safety of the packaging covers so as to prevent the release of Nano-particles.

It is shown in the research done by Ahari et al. (2009), in Tehran University article, that Nano-silver particles in direct contact have adverse effect on liver, fan chit cells and fibroblast. Therefore, the lack of release of the Nano-particles in the Nano-packaging covers is considered a main condition in packaging (Cozzolino, Nilsson, Iotti, Sacchi, Piga \& Farris 2013, Bumbudsanpharoke \& Ko 2015).

The studies carried out on how to increase the adhesion of the nano-packaging covers through the insemination study of different heats in the process of cover production, which is intended to fuse the Nano-particles into the cover, indicate that the lower the temperature, the less the herbal effective materials are destroyed and the adhesion of the cover decreases; hence, less nano-particles are coated 
and the other way round (De Silva et al. 2017, Deus, Kehrenberg, Schaudien, Klein \& Krischek 2017).

The production of nano-packaging covers with the property of changing colors through the use of sensors being tagged by them, such as gas sensors and biosensors, is one of the newest branches of nano-packaging which is employed for the diagnosis of product freshness, flavor, and the final quality and expiration date (via diagnostic labels with radio frequencies).

From among the tests used for approving and validating the production of Nano-particles in Nano-packaging covers, it can be referred to the visible-ultraviolet spectroscopy. In this method, Nano-particles are produced in a very short time (the matter of few minutes). This is while the production of these particles through other methods such as light radiation, takes several hours. Usually the silver Nano-particles peak is observed in 400-450 nanometer range which has a maximum and is in a disk and sphere form. The existence of this peak in the graph is resulted from visible spectroscopy graphs; and its symmetry is indicative of the homogeneity of the particles. Similarly, the tests of the SEM (Electron Microscope) for evaluating the size of particles and TEM, XRD and AFM microscopes were employed for imaging the covers.

The other test used in confirming the covers in terms of being Nano is the X-ray diffraction range. This test indicates the success of silver metal being successfully coded on the covers.
Similarly, the horizontal force microscope test is also utilized (Kogure et al. 2007, Hyeon, Kim \& Park 2013, Gallocchio et al. 2016) .

\section{5-Silver Composites Function Mechanism against Micro-organisms:}

The fatal effect of the silver Nano-particles starts with the attachment of the Nano-particles to the surface of the membrane and impede certain cellular activities like respiration, metabolism, membrane transfers, etc. this theory is influenced by the small size of the silver Nanoparticles. In other words, the smaller the Nanoparticles, the higher the effectiveness, as with the increase of particles surface, their attachment to the surface of the micro-organism cells surface increases and consequently, their antibacterial property is also enhanced. The silver Nano-particles dialyze the lipopolysaccharide molecules, enter the cell and augment the penetrance of the membrane. Upon the entrance and attachment to DNA, they prevent the reproduction of bacteria DNA, hence bacteria do not reproduce and gain bacteriostatic Bactericidal acetate quality. The silver ions destroy the bacteria through substitution reaction of $\mathrm{SH}$ bands in the bacteria membrane to Ags (Silver sulfide) and project bactericide qualities (D. Li et al. 2017).

Based on the published articles, the Nanoparticles, smaller than 20 nano-meters, easily influence pseudomonas and E. coli bacteria in the packaging covers. The antibacterial qualities of nano-material photo catalysts such as $\mathrm{Tio}_{2}$ which enjoys photo catalytic qualities has shown 
that there is a strong bound between the Nanoparticles of $\mathrm{Tio}_{2}$ and the outer layer of Staphylococcus areus bacteria, so that it brings about the impediment of the transfer and enzyme activities in the space between plasma membrane and bacteria cell wall and ultimately leads to Liz bacteria cell Of the bacteria cell, impediment of the DNA and protein syntheses, and consequently, the death of cell due to the termination of its vital activities.

\section{6-Determining the Zeta Potential for} Measurement of Diameter and Distribution of Nano-particles:

Nano-emulsions and Nano-packaging produced using zeta seizer machine are measured and determining the size of particles using this machine is with the help of photodynamic method. The Brownian motion of these particles are measured inside the colloid systems. This machine is capable of calculating the distribution of Nano-particles sizes based on he averages light intensity (Z-Average), in a way that the larger the diffracted light intensity particles, the less the brawny movement of the nano-particles and the average diameter of the nano-particles are reported as the average ZAverage Finally, the Nano-emulsions stability test is conducted as they are transferred to the 20 to 30 nano-meter bottles with a plastic lid, wrapped in aluminum foil, and kept in 30 degrees of centigrade for 3 months. By observing the apparent status and measuring the changes happening in the average diameter of Nano-particles in 30 to 60 days' time intervals
(PSA) is evaluated. Ultimately, PSA system is another device that hands us a graph representing the scatter of the particles composing the cover (D. Li et al. 2017, L. Li et al. 2017).

\section{Conclusion}

Nano-technology as a novel field of science has potentials for improvement of the quality and safety of the food products. The most prevalent function of Nano-technology is in packaging and diagnosis of the food pathogenic factors. Due to the change in the molecular structure of the covers, this science has made a significant revolution in the packaging industry. As Nanocovers are impervious to oxygen and moisture, silver particles can prevent the growth of bacteria and mildew in the food products packaging and lead to a sharp decrease in the clutch of food products. Today, using zinc Nano-composites like Nano-titanium dioxide in food packaging has also had a paramount effect in controlling the contamination of products and increasing their shelf-life without apparent and physical changes of the product. Beside increasing the shelf-life and lag phase, one of the basic implications of Nano-packaging covers is increasing the durability phase (stability phase) which in line with the discretion of the producer can improve the sensual quality of the packaged samples. These samples can change in terms of texture, smell and color depending $\mathrm{n}$ the additives added to the Nano-packaging covers and resolve the unpleasant smells disseminated from chicken, fish and shrimp in most of the 
cases (Shahbazzadeh et al. 2009, Moaddab et al. 2011, Shahbazzadeh et al. 2011, Soltani, Esfandiary, Sajadi, Khazraeenia, Bahonar \& Ahari 2011).

\section{References}

Ahari, H., Dastmalchi, F., Ghezelloo, Y., Paykan, R., Fotovat, M. \& Rahmannya, J. (2008) The application of silver nano-particles to the reduction of bacterial contamination in poultry and animal production. Food Manufacturing Efficiency 2(1), 49.

Ahari, H., Kakoolaki, S. \& Anvar, S.A.A. (2017) Detection of Salmonella typhi using four developed kits of ELISA for cleaning in place purification. International Journal of Environmental Science and Technology 1-6.

Alinejad Dizaj, M., Mahdaviani, S.A., Tabarsi, P., Ahari, H., Ebrahimi, A., Nadji, S.A., Emami, H. \& Mortaz, E. (2016) Association of Mycobacterium infections in patients with Mendelian susceptibility to mycobacterial disease with venous thromboembolism. Microbiology and immunology 60(10), 678-686.

Bumbudsanpharoke, N. \& Ko, S. (2015) Nanofood packaging: an overview of market, migration research, and safety regulations. Journal of Food Science 80(5), R910-923.

Carbone, M., Donia, D.T., Sabbatella, G. \& Antiochia, R. (2016) Silver nanoparticles in polymeric matrices for fresh food packaging.
Journal of King Saud University - Science 28(4), 273-279.

Cozzolino, C.A., Nilsson, F., Iotti, M., Sacchi, B., Piga, A. \& Farris, S. (2013) Exploiting the nano-sized features of microfibrillated cellulose (MFC) for the development of controlled-release packaging. Colloids Surf B Biointerfaces 110, 208-216.

De Silva, R.T., Mantilaka, M.M., Ratnayake, S.P., Amaratunga, G.A. \& de Silva, K.M. (2017) Nano-MgO reinforced chitosan nanocomposites for high performance packaging applications with improved mechanical, thermal and barrier properties. Carbohydrate Polymers 157, 739-747.

Deus, D., Kehrenberg, C., Schaudien, D., Klein, G. \& Krischek, C. (2017) Effect of a nanosilver coating on the quality of fresh turkey meat during storage after modified atmosphere or vacuum packaging. Poultry Science 96(2), 449457.

Duncan, T.V. (2011) Applications of nanotechnology in food packaging and food safety: barrier materials, antimicrobials and sensors. The Journal of Colloid and Interface Science 363(1), 1-24.

Farrokhi, S., Ahari, H. \& Abedini, M.R. (2016) Comparative effects of colloidal silver nanoparticles used in packaging film and spray in inactivating bacteria experimentally added to 
chicken eggshells. International Journal of Food Properties, 1-9.

Gallocchio, F., Cibin, V., Biancotto, G., Roccato, A., Muzzolon, O., Carmen, L., Simone, B., Manodori, L., Fabrizi, A., Patuzzi, I. \& Ricci, A. (2016) Testing nano-silver food packaging to evaluate silver migration and food spoilage bacteria on chicken meat. Food additives \& contaminants Part A Chemistry, analysis, control, exposure \& risk assessment 33(6), 1063-1071.

Hannon, J.C., Kerry, J.P., Cruz-Romero, M., Azlin-Hasim, S., Morris, M. \& Cummins, E. (2016) Human exposure assessment of silver and copper migrating from an antimicrobial nanocoated packaging material into an acidic food simulant. Food and Chemical Toxicology 95, 128-136.

Huang, J.-Y., Li, X. \& Zhou, W. (2015) Safety assessment of nanocomposite for food packaging application. Trends in Food Science \& Technology 45(2), 187-199.

Hyeon, D.J., Kim, T.H. \& Park, L.S. (2013) Effect of nano-silica filler on the uniform packaging of white light emitting diodes. Journal of Nanoscience and Nanotechnology 13(9), 5976-5981.

Kogure, K., Akita, H. \& Harashima, H. (2007) Multifunctional envelope-type nano device for non-viral gene delivery: concept and application of Programmed Packaging. Journal of Controlled Release 122(3), 246-251.

Li, D., Ye, Q., Jiang, L. \& Luo, Z. (2017) Effects of nano-TiO2 -LDPE packaging on postharvest quality and antioxidant capacity of strawberry (Fragaria ananassa Duch.) stored at refrigeration temperature. Journal of the Science of Food and Agriculture 97(4), 1116-1123.

Li, L., Zhao, C., Zhang, Y., Yao, J., Yang, W., Hu, Q., Wang, C. \& Cao, C. (2017) Effect of stable antimicrobial nano-silver packaging on inhibiting mildew and in storage of rice. Food Chemistry 215, 477-482.

Lin, Q.B., Li, H., Zhong, H.N., Zhao, Q., Xiao, D.H. \& Wang, Z.W. (2014) Migration of Ti from nano- $\mathrm{TiO}(2)$-polyethylene composite packaging into food simulants. Food additives \& contaminants Part A Chemistry, analysis, control, exposure \& risk assessment 31(7), 1284-1290.

Luo, Z., Wang, Y., Wang, H. \& Feng, S. (2014) Impact of nano-CaCO3 -LDPE packaging on quality of fresh-cut sugarcane. Journal of the Science of Food and Agriculture 94(15), 32733280.

Moaddab, S., Ahari, H., Shahbazzadeh, D., Motallebi, A.A., Anvar, A.A., Rahman-Nya, J. \& Shokrgozar, M.R. (2011) Toxicity Study of Nanosilver (Nanocid) on Osteoblast Cancer Cell Line. International Nano Letter 1, 11-16. 
Ramos, M., Jimenez, A., Peltzer, M. \& Garrigos, M.C. (2014) Development of novel nano-biocomposite antioxidant films based on poly (lactic acid) and thymol for active packaging. Food Chemistry 162, 149-155.

Shahbazzadeh, D., Ahari, H., Motalebi, A., Anvar, A., Moaddab, S., Asadi, T., Shokrgozar, M. \& Rahman-Nya, J. (2011) In vitro effect of Nanosilver toxicity on fibroblast and mesenchymal stem cell lines. Iranian Journal of Fisheries Sciences 10(3), 487-496.

Shahbazzadeh, D., Ahari, H., Rahimi, N.M., Dastmalchi, F., Soltani, M., Fotovat, M., Rahmannya, J. \& Khorasani, N. (2009) The Effects of Nanosilver (Nanocid®) on Survival Percentage of Rainbow Trout (Oncorhynchus mykiss). Pakistan Journal of Nutrition 8(8), 1178-1179.

Soltani, M., Esfandiary, M., Sajadi, M., Khazraeenia, S., Bahonar, A. \& Ahari, H. (2011) Effect of nanosilver particles on hatchability of rainbow trout (Oncorhynchus mykiss) egg and survival of the produced larvae. Iranian Journal of Fisheries Sciences 10(1), 167-178.

Srividya, N., Ghoora, M.D. \& Padmanabh, P.R. (2017) Antimicrobial nanotechnology: research implications and prospects in food safety. 125165.

Su, Q.Z., Lin, Q.B., Chen, C.F., Wu, L.B. \& Wang, Z.W. (2017) Effect of organic additives on silver release from nanosilver-polyethylene composite films to acidic food simulant. Food Chemistry 228, 560-566.

Tierney, K.B. (2017) The Effects of Toxicants on Olfaction in Fishes. Reference Module in Life Sciences, Elsevier.

Vera, P., Echegoyen, Y., Canellas, E., Nerin, C., Palomo, M., Madrid, Y. \& Camara, C. (2016) Nano selenium as antioxidant agent in a multilayer food packaging material. Analytical Bioanalytical Chemistry 408(24), 6659-6670.

Yamada, Y., Kogure, K., Nakamura, Y., Inoue, K., Akita, H., Nagatsugi, F., Sasaki, S., Suhara, T. \& Harashima, H. (2005) Development of efficient packaging method of oligodeoxynucleotides by a condensed nano particle in lipid envelope structure. Biological and Pharmaceutical Bulletin 28(10), 1939-1942. 


\title{
استفاده از نانواموليسيون هاى نوآورى شده و يوشش هاى كاميوزيتى نانونقره براى خواص آنتى باكتريال: مقاله مرورى \\ دكتر حامداهرى \\ 'دانشكده علوم و مهيندسى صنايع غذايى، واحد علوم و تحقيقات تهران، دانشعاه آزاد اسلامى، تهران، ايران
}

\begin{abstract}
جكيده
امروزه استفاده از فناورى هاى نوين نانو در حوزه كنترل كيفيت صنايع غذايى رشد بسيار جشمخيرى داشته و در كرايش هاى

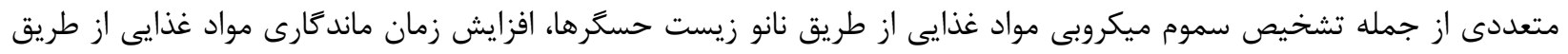

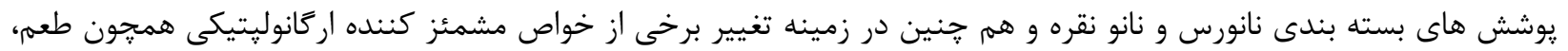

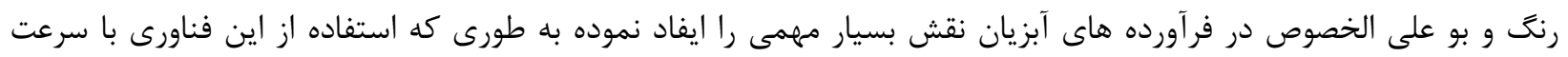
بسيار زيادى در حال رشد و توسعه مى باشد. كرايش هاى متعددى از اين فناورى همجون Nano Injection در حوزه هاى يزشكى به منظور تزريق تركيبات شيميايى در

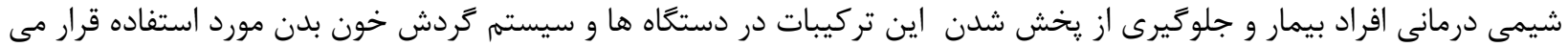

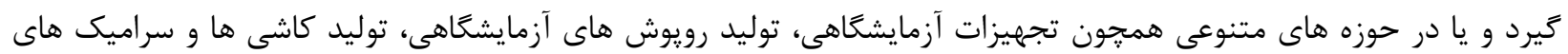

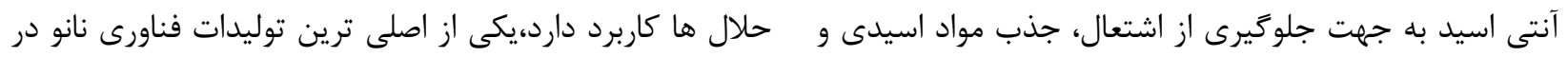

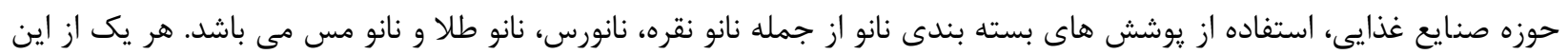

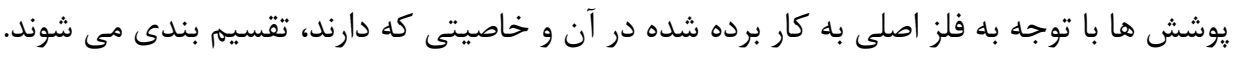

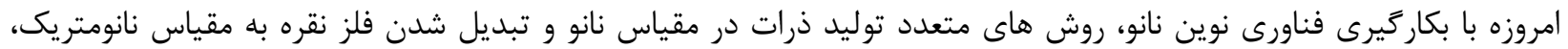
تمامى خصوصيات آنتى باكتريال آن به ميزان بسيار زيادى افزايش و مصارف كوناگونى از جمله كاربرى در يوشش هاى نائ بسته بندى

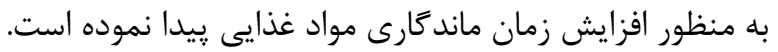

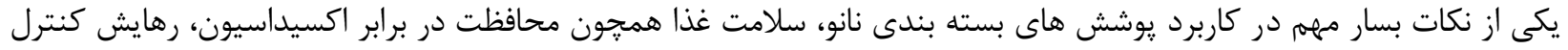

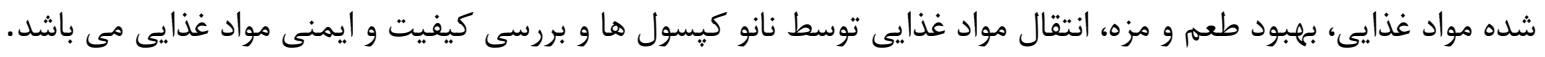

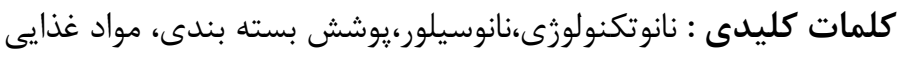
Dr.h.ahari@gmail.com نويسنده مسئول:
\end{abstract}

